\title{
Typography and national identity
}

This text focuses on the concept of tradition founded on nationalist bases and asks how it is related to graphic design. This question is considered in the field of typography, where ties between the printing industry, language and national identity are illustrated. Three principles from theories of nationalism are followed and compared with some episodes of typography history. The concepts are, first and foremost, Anderson's thesis that the printed language helped found nationalism. Second, Hobsbawm's idea that nationalism is able to invent traditions. Third, Gellner's point that nationalism tries to align cultural and political frontiers. It is thus suggested that nationalism is related to graphic design as an unintended effect of the printing industry. However, since typography precedes nations, it does not necessarily convey national identities. Nationalist commitments may attribute false historical origins to typefaces and restrict design to national borders that do not correspond to the cultural ones.

keywords design, memory, nationalism, typography

\section{Introduction}

Criterias based on national identity have been influencing the practice of design, as well as the way its history is structured. Clients demand projects that express it and researchers often divide history according to nationalities. Determining the specific characteristics of countries, however, is difficult, for they are often vague or contradictory. Theories of nationalism developed by Anderson, Hobsbawn and Gellner' state that, although nations assert to have ancient roots, they are actually relatively recent, rising notably from the XIX century onwards. The gap between the claimed and the real origins of nations is confirmed when nationalism is observed from the perspective of typography.

Before the XIX century, type was seldom regarded as symbol of national identity. The use of blackletters, more common in Protestants than in Catholics publications in the $\mathrm{XVII}$ century, had then no national connotation. The expansion of nationalism in the late XIX century in Germany coincided with the promotion of blackletter as a national type. The comparison between the use of typography in the unification of Germany and in the independence of the United States indicates that the commitment to the image of a country is a relatively recent invention.

'This essay is centered in the "modernist" perspective of nationalism, as opposed to the "primordialist" stance that nations have ancient origins. Modernist theories argue that capitalism propelled nationalism. Anderson remarks that print itself does not lead to national communities. The technique already existed in China - before reaching Europe - but did not result in nationalism because there were no capitalist forces shaping the languages. No reference is made here to Marshall McLuhan, for he does not belong to this theoretical framework. Modernist theories do not assume that social organization is in first instance caused by technology. 
Anderson argues that nationalism was gradually built as an effect of the combination of capitalism, printing technology and the diversity of languages. Type, as an industry that spreads languages, helped engender the broad idea of nationalism - which does not mean that particular typographic styles have, or should have, particular national attributes. On the contrary, typography is historically older than nations. Thus, types are more logically linked to nations as a preceding cause than as a subsequent effect.

\section{Types, languages, nations}

Opposing the belief that nations evolved from time immemorial, researchers have stressed that nationalism is tied to capitalism, industrialization and modernity. "Nationalism provides perhaps the most compelling identity myth in the modern world", says Smith (1991, p.VIII). Language is one of the sources of this mythical identification. So if a government chooses one vernacular for bureaucratic and administrative purposes, this decision is likely to have nationalist implications (Gellner 1997, p.39). The printing industry, by fitting written languages to capitalism, was a decisive factor in the building of nationalism.

Anderson points out that, though language itself does not invent nationalism, the combination of capitalism, movable type and language does. Print-capitalism formed standardized languages in order for books to reach new markets. These languages were based on related dialects which sounded different but could be read by their speakers. Through the printed word, they could understand each other and realize that they belonged to the same linguistic field. The apparent fixity of the print-language helped promote the idea of antiquity on which nations rely.

Gutenberg and the first European printers reproduced texts in Latin, which required bilingual readers. This market was soon saturated. In contrast, Luther's works written in German in the XVI century were so successful that he is perhaps the first author of bestsellers. The potential market of monolinguals seemed to be an alternative to the market of Latin readers. Print-capitalism advanced on this direction.

Latin, says Anderson, represented the imagined community of the Catholic Church - and the printed vernacular helped dismantle this community. As it was decaying, the national imagined communities began to consolidate. In typography, the ideological polarization between "roman" letters and "blackletters" shows this development. Initially, in the $\mathrm{XVI}$ century, printing with either group stamped the difference between Catholics and Protestants. Roman letterforms prevailed in the Vatican, whereas protestant publications had usually blackletters. In the late XIX century, nationalism led blackletters to be considered a cultural heritage of the recently unified Germany.

As Burke (1998) quoted, for chancellor Otto von Bismarck, writing in German with roman letters was as anachronistic as writing in French using "German" letters (ie blackletters). It is unlikely, however, that roman types were not related to Germany. Since the first moveable types of Europe were made in Germany, German craftsmen had the necessary knowledge to create the first roman types. Indeed, Johann and Wendelin da Spira, as well as Sweynheym and Pannartz, all born in places known today as Germany, produced in Venice and Rome the first characters similar to roman (figure 1).

If Bismarck justified his preference considering "non-German" types whose origin actually points to Germany, the Nazis later went even further, decreeing the use of blackletters 


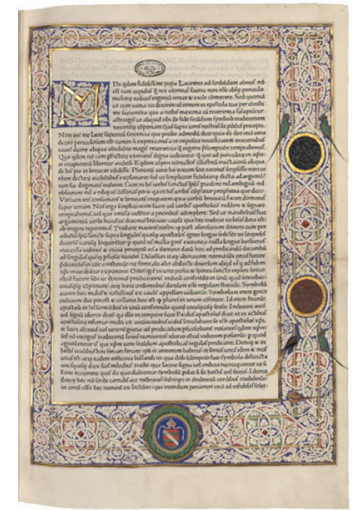

Figure 1.

St Jerome,

Epistula printed by

Sweynheym and

Pannartz in Rome

in 1468. Vatican

Library.

Source:

www.vaticanlibrary.va

in 1933 and arresting those who opposed it, such as typographers Paul Renner and Tschichold. Eight years later, they proclaimed the contrary: roman letters were officially adopted. The inconsistency of their nationalistic appropriation of letterforms became clear in this changing of position.

All these letters are probably connected when the origin of their drawings is examined. Noordzij argues that blackletter and roman are based on related calligraphic structures. During the Middle Ages, subtle differences in the usage of pen gradually resulted in calligraphies that served as models for roman, blackletter and italic. "For every writer a different letter width feels normal and every pen has a different width" (Noordzij 2005, p. 58). So different tools and techniques produced different forms of writing, which otherwise have a common structure.

Noordzij focused on describing the properties of shapes "without imposing aesthetic or ideological conditions" (2005, p.10). It can be inferred that these ideological conditions are linked to the age of print-capitalism - before that, the boundaries between what we now refer to as roman and blackletter were less demarcated. Noordzij's theory is in tune with Anderson's arguments. The effect of print-capitalism in the shape of letters was analogous to its effect in the languages: it fixed, standardized and modulated, accentuating the contrast between different elements and the identity between similar ones.

\section{National differences}

As this industry defined and spread vernacular languages, it was also defining a cultural universe encompassed by these languages. But despite this common universe, the advent of the newspaper revealed the difference between speakers of the same language who lived, for example, in the colonial or in the metropolitan areas (Anderson 1991). Significantly, one of the leaders of the American independence, Benjamin Franklin, was a printer and a newspaper owner.

Franklin's approach to typography, however, attested that the establishment and independence of a nation initially was not expressed in typographic shapes. Franklin was the editor of one of the firsts newspapers of the colony. He subsequently moved to England, working as a printer in one of the leading printing companies in London. Its owner, John Watts, was one of the financiers of William Caslon, who at that time was 
theme 2

memory

Figure 2.

Declaration of independence of the United States, 1776. Library of Congress.

Source: www.loc.gov strand 1

design histories: tradition, transgression and transformations

developing his typeface. Benjamin was interested in the craft - nonexistent in the colony - of the production of types. So three years after the release of Caslon typeface, Franklin, back to America and then the owner of The Pennsylvania Gazette, purchased the font for his newspaper.

He chose Caslon for the first edition of the American Declaration of Independence, so typography then was not related to nationalism (figure 2). American typefaces with a supposed national identity were impractical at that time, since there were no type foundries in the United States. But, regardless of viability, Franklin did not seem to be concerned with this issue. Around the XVIII century, the topic of national identity was not too manifest yet.

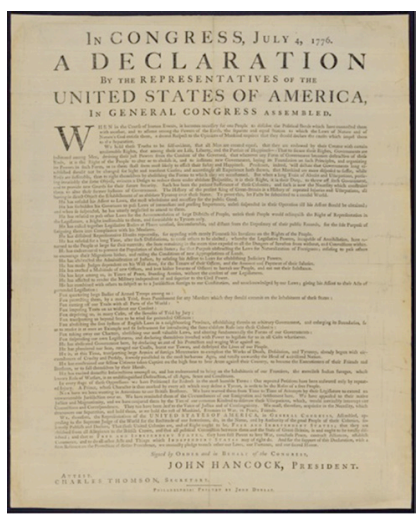

\section{Inventions and traditions}

The spread of national identities became more explicit and frequent from 1870 to 1914 (Hobsbawm 2003). Holidays, costumes, monuments and emblems, introduced and systematically repeated, are some examples of invented traditions. They promote the idea of continuity with the past and help grant cohesion to a group. And although modern nations are relatively recent, they "generally claim to be the opposite of new, ie, rooted in the remotest antiquity, and the opposite of communities that were built " (2003, p.23).

Hobsbawom notes that, in the United States, these traditions helped assimilate the heterogeneous and abundant flow of new immigrants arriving in the late XIX century. Independence Day and Thanksgiving started being celebrated on a national scale in this period. Conversely, immigrants' traditions such as St. Patrick's Day were absorbed.

Meanwhile, in 1902, Morris Fuller Benton created Franklin Gothic, the typeface named after Benjamin Franklin that may seem tipically American. Benton also produced versions of European typefaces such as Garamond and Bodoni, which indicates the coexistence of different styles in the country. As Souza (2008, p. 51) comments, American design "was not concerned with the strict definition of aesthetic standards".

It can be claimed that diversity is a typical characteristic of the American identity. Plurality might indeed be a concept aligned with the imagery of a free country, often used by the United States. It is also possible, however, that design has sometimes been a pragmatic 
response to practical demands - rather than the result of a search for a national essence. The example of blackletters in the nazi Germany, imposed and banned in a short period, indicates that nationalists arguments alone may sometimes be grounded on fictitious traditions.

\section{Nation and culture}

One of the paradoxes of national identity in typography is the fact that national and linguistic areas often do not coincide. This divergence is exemplified by indigenous languages of South America, whose groups of speakers are located in several countries. The linguistic branches of Guarani, for example, are spoken in Brazil, Bolivia, Argentina, Paraguay and Uruguay (figure 3).

In Brazil, indigenous groups are usually seen as national symbols. This is the case of Guarani tribes, which inspired Brazilian art in the second half of the XIX century. Nowadays, XIX century novel "O Guarani" is part of the curriculum of Brazilian schools, and the homonym opera "O Guarani" opens governmental radio programs. In other words, national institutions have been indirectly using the image of indigenous groups.

Brazilian type designer Rafael Dietzsch has observed that Guarani languages - as many other indigenous languages of South America - require specific glyphs that most typefaces do not take into account. His typeface Brasílica addresses this kind of problem. Brasílica may be considered an authentic national typeface, but, strictly speaking, it is not exclusively Brazilian, neither are the indigenous Guarani groups.

As Gellner (1997) remarks, the need for convergence between political and cultural areas is peculiar to nationalism. Nationalist movements derive from strives to grant an independent state to a culture, or, conversely, to define the culture of an already established state. Agrarian societies had political boundaries much larger or smaller than the cultural regions, and they did not attempt to merge state and culture as nationally organized societies do.

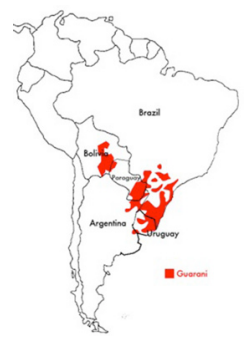

Figure 3. Guarani-speaking areas (red). Map based on Jost Gippert's map of languages of South America. Source: Institute of Comparative Linguistics of the Johann Wolfgang Goethe-Universität

\section{Conclusion}

Design deals with cultural contexts that can sometimes be unrelated to the geographic area of a nation. Furthermore, the identity of a country is not immutable. Perhaps printlanguage was decisive in the development of nationalist sentiments - but typography itself is essentially international. In the XV century, typographers and types crossed areas that today represent national frontiers, and reproduced texts in different languages and cultures. 
This circulation carried this craft - which predates nationalities - to places where printing was possible. Types made in England reached the American continent. They were used in publications of the independence movement - against England - in the United States. German type cutters settled in Italy cast the first roman types. The reproduction of texts do not require typefaces made locally - or by local authors - and its spread happened thanks to the migration of craftsmen.

The logic of the advantage of the national product implies the disadvantage of the international one. This same logic, if reciprocally adopted, restricts the international circulation of products and techniques made locally. Regarding type, an extremely protectionist logic would have prevented the production of printed texts outside what is now Germany.

Since at that time Germany did not exist as a nation, typographic techniques were spread, ultimately reaching different continents. The multiplication of the written word is the one of the main principles of typography. Variations in typographic forms emerge and keep circulating when they are appreciated, but this circulation often goes beyond nationalities.

The attempt to define what is typically national can lead to stereotypes that may not be very functional from a typographical perspective. Moreover, the attempt to find a national tradition by tracing some continuity with the past is usually contradicted by the existence transnational mutual influences. "Stereotypes", "traces", "imagined communities": maybe it is difficult to accurately enumerate the typically national characteristics because they are not exact. They are malleable, mutable and perhaps sometimes unnecessary.

\section{References}

Anderson, B. (1991) Imagined Communities. London; New York: Verso Burke, C. (1998) Paul Renner the art of typography. London: Hyphen Press Gellner, E (1997) Nationalism. New York: New York University Press Hobsbawm, E (2003) The invention of tradition. Cambridge: University Press Institute of Comparative Linguistics of the Johann Wolfgang Goethe-Universität (2003). Languages of South America. http://titus.uni-frankfurt.de/didact/karten/amer/samerim. $\mathrm{htm}$ Accessed 02-04-2014 Library of Congress (n.d.) Declaration of independence http://www.loc.gov/rr/program/ bib/ourdocs/Declarlnd.html Accessed 10-12-2013 Noordzij, G. (2005) The stroke theory of writing. London: Hyphen Press Smith, A. (1991) National identity. London: Penguin Books Souza, P. L. P. (2008) Notas para uma história do design. Rio de Janeiro: 2AB Vatican Library (n.d.) Historical notes. http://www.vaticanlibrary.va/home. php?pag=sezione_editoria\&ling=eng Accessed 10-12-2013 